\title{
Analysis of Articles of Fixed Assets Renewal of Rus- sian Business Enterprises
}

\author{
Nechaev Andrey Sergeevich \\ Department of Industrial Management, \\ Institute of Economics, Management and Law, \\ Irkutsk National Research Technical University \\ Irkutsk, Russian Federation \\ n-a-s@mail.ru
}

\author{
Barykina Yuliya Nikolaevna \\ Department of Industrial Management, \\ Institute of Economics, Management and Law, \\ Irkutsk National Research Technical University \\ Irkutsk, Russian Federation \\ Spasio71@yandex.ru
}

\author{
Puchkova Nataliya Viktorovna \\ Institute of Economics, Management and Law, \\ Irkutsk National Research Technical University \\ Irkutsk, Russian Federation \\ pnv_v217@mail.ru
}

\begin{abstract}
In the present article, the topicality of the chosen research theme is given proof. The need of the analysis of articles of fixed assets renewal of Russian business enterprises conditions not only a high level of competitive ability and effectiveness of activity, but also makes it possible to decrease process cost. Further, within the scope of the research, some problem aspects of articles of fixed assets renewal of the business enterprises resisting renewal of capital assets, are considered. On the ground of official data of Federal State Statistics Service, such indicators of capital movement as retirement and renewal rates (as percentage of capital fund availability at the end of the year), startup of capital assets (cost and structure), the degree of depreciation (overall figures of all economic activities), a fraction of fully depreciated capital assets (by individual industries and types of basic funds) and depreciation charge amount (cost and as percentage of basic assets availability) are analyzed (as exemplified by Russian business enterprises, including types of economic activities). For an analyzed period, the radius from 2014 to 2016 is chosen. Then according to the results of the analysis, some principal factors manipulating effectiveness of fixed assets renewal are singled out, the need of well-timed and full business capital renewal is confirmed and some recommendations of its optimization are given.
\end{abstract}

Keywords - fixed assets, reproduction, capital movement showing, capital assets, business capital.

\section{INTRODUCTION}

Fixed assets have one of the priority senses in the forming of effective activity of any enterprise, as long as they either directly take part in the production manufacturing process/ rendering services or create necessary conditions for the work flows. There are many classifications of fixed assets, but, generally, they consist of buildings, constructions, machine and equipment, apparatuses and devices, transport vehicles, toolware and inventory, productive livestock and pedigree cattle, perennial planting and so on [5].

The availability and qualitative structure of fixed assets at an enterprise condition not only its economic independence, competitive strength and financial sustainability, but also are an important factor in the development of all economy in whole, since they directly influence the progress of marketed relations [9].

Today the problem of company provision by basic production assets and optimality of their use is very urgent because plenty of current reequipment mechanisms and reproduction of capital are not high-performance. In this connection, it is necessary to carry out an analysis for the current state of fixed assets renovation process in accordance with the following data:

TABLE I. COEFFICIENT OF RENEWAL AND RETIREMENT RATE OF FIXED ASSETS IN RUSSIAN FEDERATION BY LINE OF BUSINESS (IN COMPARABLE PRICES):

\begin{tabular}{|c|c|c|c|}
\hline Index number: & 2014 & 2015 & 2016 \\
\hline \multicolumn{4}{|c|}{$\begin{array}{l}\text { Coefficient of renewal (new fixed assets, as percentage of fixed assets } \\
\text { availability at the end of year), } \%\end{array}$} \\
\hline All fixed assets & 4.6 & 4.3 & 3.9 \\
\hline \multicolumn{4}{|c|}{ According to lines of business: } \\
\hline rural economy and forestry & 4.3 & 4.0 & 3.9 \\
\hline fishery and fish breeding & 3.2 & 3.9 & 2.8 \\
\hline mining operations & 6.8 & 5.8 & 6.6 \\
\hline manufacturing activity & 6.9 & 6.9 & 6.3 \\
\hline $\begin{array}{l}\text { production and distribution of electric- } \\
\text { ity, gas and water }\end{array}$ & 5.7 & 5.1 & 4,0 \\
\hline building & 4.3 & 3.8 & 3.4 \\
\hline $\begin{array}{l}\text { distributive industries (wholesale and retail } \\
\text { trade) }\end{array}$ & 6.5 & 7.5 & 6.2 \\
\hline hotels and restaurants & 3.3 & 3.5 & 2.8 \\
\hline transport and communication & 4.2 & 4.0 & 3.2 \\
\hline financing activity & 10.6 & 7.9 & 7.1 \\
\hline real estate operations & 2.6 & 2.6 & 2.5 \\
\hline public administration and security & 6.2 & 5.0 & 5.7 \\
\hline education & 4.2 & 3.3 & 2.8 \\
\hline public health and social services & 5.8 & 3.8 & 2.9 \\
\hline rendering of other services & 4.7 & 2.9 & 3.4 \\
\hline \multicolumn{4}{|c|}{$\begin{array}{l}\text { Retirement rate (fixed assets liquidation, as percentage of fixed assets } \\
\text { availability at the beginning of year), } \%\end{array}$} \\
\hline All fixed assets & 0.7 & 0.8 & 1.0 \\
\hline \multicolumn{4}{|c|}{ According to lines of business: } \\
\hline Index number: & 2014 & 2015 & 2016 \\
\hline
\end{tabular}


rural economy and forestry

\begin{tabular}{|l|l|l|l|} 
rural economy and forestry & 2.1 & 1.8 & 2.1 \\
\hline fishery and fish breeding & 0.9 & 3.0 & 0.9 \\
\hline mining operations & 0.8 & 0.8 & 1.1 \\
\hline hotels and restaurants & 0.6 & 0.5 & 0.7 \\
\hline transport and communication & 0.3 & 0.4 & 0.4 \\
\hline financing activity & 1.1 & 1.2 & 1.6 \\
\hline real estate operations & 0.5 & 1.1 & 1.4 \\
\cline { 1 - 2 } public administration and security & 0.8 & 1.0 & 1.0 \\
\hline education & 0.7 & 0.6 & 0.8 \\
\hline public health and social services & 1.7 & 1.1 & 1.1 \\
\hline rendering of other services & 0.7 & 0.4 & 0.6 \\
\hline
\end{tabular}

For the greater obviousness of the comparative movement of basic indicators, it is rational to show the data introduced in Table 1 by means of the diagram of the coefficient of renewal and retirement rate of basic assets movement:

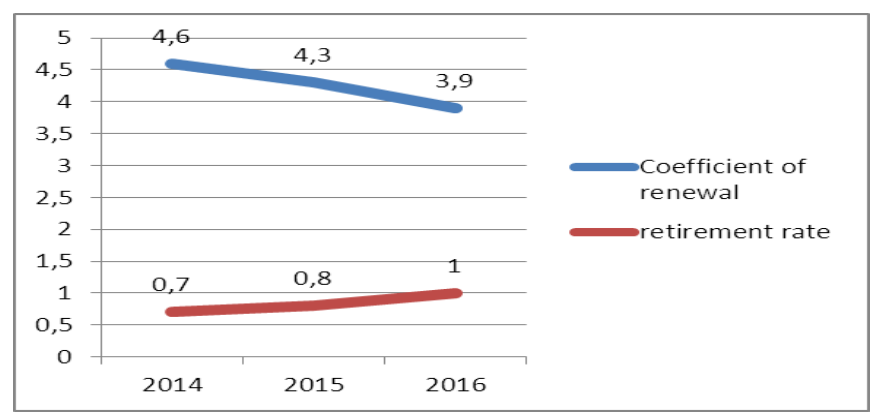

Fig. 1. Comparative movement of asset transaction coefficients in the period from 2014 to 2016

Basing on the data shown in Figure 1 and Table 1, it can be concluded that the dynamics of changing of fixed assets movement coefficients has a considerable gap ( the limit of the value of the coefficient of renewal is from « $3,9 »$ to $« 4,6 »$, and that of the retirement rate is from $\langle 0,7 »$ to $\langle 1 »)$. This fact can mean that Russian enterprises follow extended reproduction tactics (profiliration of means of labour). This can be conditioned by the availability of free production space and maximum machine utilization. The given way of capital renewal is actual at a high level of demand and buying power, which is impossible to say about the Russian market. Also the given situation can give evidence of Russian enterprises innovative activity decrease due to labour means qualitative development slowdown [10].

The dynamics of each coefficient can be described in the following way:

Starting from 2014 up to the present, the growth of the coefficient of renewal is taking place that may refer to business capital decreasing, and this, in turn, predetermines reduction of final products quantity of output and its degradation. This substantially impairs the ability of the analyzed enterprises to compete. In respect of retirement rate, very slight growth from 2014 up to the present is observed [2]. This could point to the working life reduction of the elements of fixed assets that would benefit the development of marketed relations of the Russian enterprises, if the value of the retirement rate weren't so negligible.

For the more detailed study, it is necessary to consider the reasons for the revealed dynamics structurally according to each coefficient of fixed assets movement. To begin with, one should study the following analytical table:
TABLE II. NEW FIXED ASSETS IN RUSSIAN FEDERATION BY LINES OF BUSINESS (MILLION RUBLES)

\begin{tabular}{|l|l|l|l|}
\hline & \multicolumn{1}{|c|}{$\mathbf{2 0 1 4}$} & \multicolumn{1}{|c|}{$\mathbf{2 0 1 5}$} & \multicolumn{1}{|c|}{$\mathbf{2 0 1 6}$} \\
\hline All fixed assets & 10887946 & 10721081 & 11295086 \\
\hline \multicolumn{3}{|c|}{} \\
\hline rural economy and forestry & 424567 & 449408 & 525233 \\
\hline fishery and fish breeding & 15696 & 12553 & 14158 \\
\hline mining operations & 1563104 & 1921590 & 2249077 \\
\hline manufacturing activity & 1666748 & 1646172 & 1642336 \\
\hline $\begin{array}{l}\text { production and distribution } \\
\text { of electricity, gas and } \\
\text { water }\end{array}$ & 1012798 & 876551 & 807503 \\
\hline building & 210770 & 165588 & 176193 \\
\hline trade industry & 492517 & 452988 & 515901 \\
\hline hotels and restaurants & 55514 & 66922 & 73070 \\
\hline $\begin{array}{l}\text { transport and } \\
\text { communication }\end{array}$ & 2319934 & 1909505 & 1948535 \\
\hline financing activity & 388071 & 345222 & 406750 \\
\hline real estate operations & 1608346 & 1517081 & 1563299 \\
\hline $\begin{array}{l}\text { public administration and } \\
\text { security }\end{array}$ & 469601 & 662190 & 716752 \\
\hline education & 236667 & 240599 & 210398 \\
\hline public health & 199655 & 158381 & 155457 \\
\hline other services & 223958 & 296331 & 290424 \\
\hline
\end{tabular}

With reference to the data given in Table 2, one can conclude that throughout the period under review, the increase of cost value of set in operation capital assets is locked in. That may mean that with the decrease of the amount of introduced capital elements (coefficient of renewal reducing), the cost for them increases and if the effectiveness of their implementation falls short of expectations, it can threaten to worsen intensity of fixed assets renewal. For better obviousness of structural changes study, it is necessary to construct the following diagram:
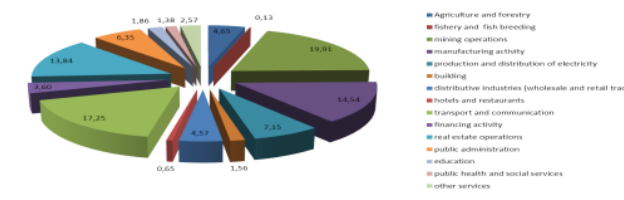

Fig. 2. The structure of new fixed assets in RF according to the data of 2016

Following the data shown in Figure 2 and Table 2, it is evident that some branches make the greatest specific weight in the input of fixed assets structure:

- $\quad$ mining operations $19.91 \%$ (2 $249077 \mathrm{mln}$. RUB.); 
- transport and communication $17.25 \%$ (1 948535 mln. RUB.);

- manufacturing activity $14.54 \%$ (1 642336 mln. RUB.);

- real estate operations $13.84 \%$ (1 563299 mln. RUB.)

The least specific weight is accounted for by:

- fishery and fish breeding $0.13 \%$ (14 $158 \mathrm{mln}$. RUB.);

- hotels and restaurants $0.65 \%$ (73 $070 \mathrm{mln}$. RUB.)

In general, this structure is fully justified by branches capital coefficient and strategic tasks of RF economy. Further, it is necessary to study the data relating to the retirement rate; for that, the following table is needed:

TABLE III. DEGREE OF DEPRECIATION OF FIXED ASSETS IN RUSSIAN FEDERATION

\begin{tabular}{|l|l|l|l|}
\hline Index number & 2014 & 2015 & 2016 \\
\hline Degree of depreciation of fixed assets, \% & 49.4 & 47.7 & 48.7 \\
\hline
\end{tabular}

In accordance with the data introduced in Table 3, it can be concluded that in the period from 2014 to 2015 the decrease by $1,7 \%$ is recorded, and from 2015 to 2016 there is the increase by $1 \%$, but, since the changes are not considerable, then one cannot definitely assess the situation. However during the whole analyzed period the degree of depreciation almost achieves critical value of 50\% (the standard value of this coefficient is not regulated by law, but only fixed in corporate accounting policy), that is indicative of a high degree of deterioration of fixed assets elements and the necessity of their rapid replacement.

Subsequently, for the completeness of the research, it is necessary to seriously study the structure of the fixed assets depreciation according to some types of activities, to achieve this it is needed to analyze the following data:

TABLE IV. THE PORTION OF FULLY DEPRECIATED FIXED ASSETS IN RUSSIAN FEDERATION IN COMMERCIAL ORGANIZATIONS BY INDIVIDUAL INDUSTRIES AND TYPES OF FIXED ASSETS, $\%$

\begin{tabular}{|c|c|c|c|}
\hline \multirow{2}{*}{ Index number } & \multicolumn{3}{|c|}{$\begin{array}{l}\text { specific weight of fully depreciated } \\
\text { fixed assets, } \%\end{array}$} \\
\hline & 2014 & 2015 & 2016 \\
\hline All fixed assets & 14.6 & 14.9 & 15.8 \\
\hline \multicolumn{4}{|c|}{ Out of them: } \\
\hline utility & 3.5 & 3.4 & 3.4 \\
\hline works & 14.2 & 14.4 & 15.0 \\
\hline machinery and equipment & 22.1 & 23.1 & 24.5 \\
\hline transport vehicles & 10.3 & 10.7 & 11.9 \\
\hline \multicolumn{4}{|c|}{ Fixed assets of organizations: } \\
\hline Agriculture and forestry & 7.0 & 7.2 & 7.5 \\
\hline \multicolumn{4}{|c|}{ Out of them: } \\
\hline utility & 2.9 & 2.5 & 2.2 \\
\hline works & 7.8 & 7.1 & 5.6 \\
\hline machinery and equipment & 10.3 & 11.4 & 12.8 \\
\hline transport vehicles & 12.3 & 12.4 & 13.9 \\
\hline mining operations & 22.9 & 21.6 & 19.9 \\
\hline \multicolumn{4}{|c|}{ Out of them: } \\
\hline utility & 7.0 & 6.8 & 7.3 \\
\hline works & 22.1 & 20.4 & 17.4 \\
\hline
\end{tabular}

\begin{tabular}{|c|c|c|c|}
\hline machinery and equipment & 32.0 & 31.5 & 33.0 \\
\hline transport vehicles & 21.8 & 20.9 & 23.0 \\
\hline manufacturing activity & 13.3 & 14.0 & 15.0 \\
\hline \multicolumn{4}{|c|}{ Out of them: } \\
\hline utility & 2.0 & 2.0 & 2.0 \\
\hline works & 9.6 & 13.1 & 13.6 \\
\hline machinery and equipment & 18.8 & 18.9 & 20.5 \\
\hline transport vehicles & 16.2 & 18.5 & 19.4 \\
\hline Building & 13.5 & 13.5 & 13.8 \\
\hline \multicolumn{4}{|c|}{ Out of it: } \\
\hline utility & 5.4 & 2.9 & 2.6 \\
\hline works & 7.4 & 9.7 & 7.3 \\
\hline machinery and equipment & 19.5 & 20.1 & 22.1 \\
\hline transport vehicles & 14.8 & 15.7 & 17.6 \\
\hline distributive industries & 18.8 & 20.3 & 23.1 \\
\hline \multicolumn{4}{|c|}{ Out of them: } \\
\hline utility & 9.1 & 9.1 & 8.5 \\
\hline works & 15.4 & 17.1 & 20.4 \\
\hline machinery and equipment & 43.2 & 43.7 & 45.4 \\
\hline transport vehicles & 4.9 & 4.9 & 6.3 \\
\hline Transport and communication & 10.8 & 11.8 & 12.9 \\
\hline \multicolumn{4}{|c|}{ Out of them: } \\
\hline utility & 4.6 & 4.9 & 5.2 \\
\hline works & 7.9 & 8.2 & 8.6 \\
\hline machinery and equipment & 21.1 & 24 & 25.8 \\
\hline transport vehicles & 8.6 & 9.2 & 10.6 \\
\hline
\end{tabular}

For the further analysis, it is necessary to methodize the data shown in Table 4 in the form of the following diagrams:

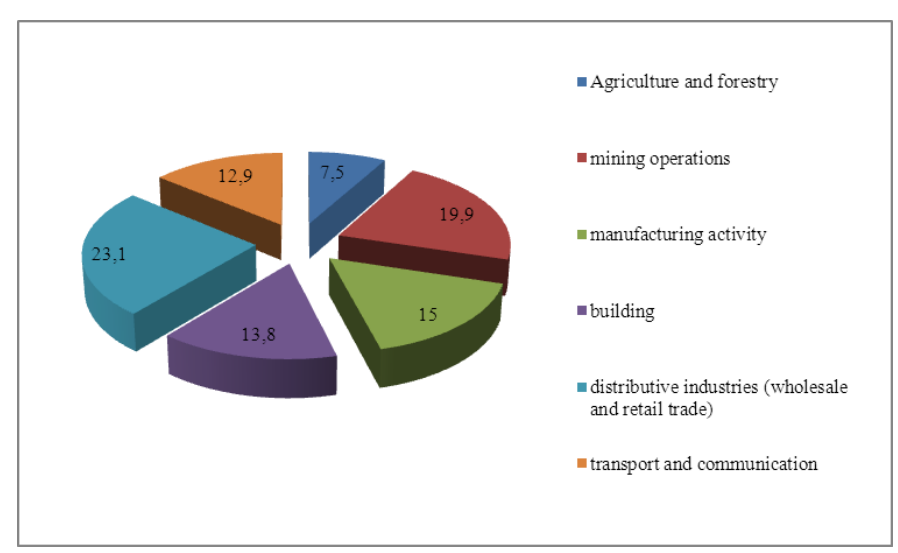

Fig. 3. The structure of fully depreciated fixed assets in 2016

Basing on the data presented in Table 4 and Figure 3, the inference should be drawn that the maximum specific weight in the structure of fully depreciated fixed assets is accounted for by:

- wholesale and retail trade: $23.1 \%$;

- mining operations: $19.9 \%$;

The dynamics of structural index number changing within the discussed period is trivial:

- wholesale and retail trade has the growth from 2014 to 2015 by $1.5 \%$ and from 2015 to 2016 by $2.8 \%$, this affected the changing of specific weight priority in the general structure: the replacement of the top ranking branch from mining operations to trading environment; 
- mining operations are reduced by $1.3 \%$ from 2014 to 2015 and by $1.7 \%$ from 2015 to 2016 .

To figure out the reason of such a situation, it is essential to consider at the cost of what elements of fixed assets the changes have occurred:

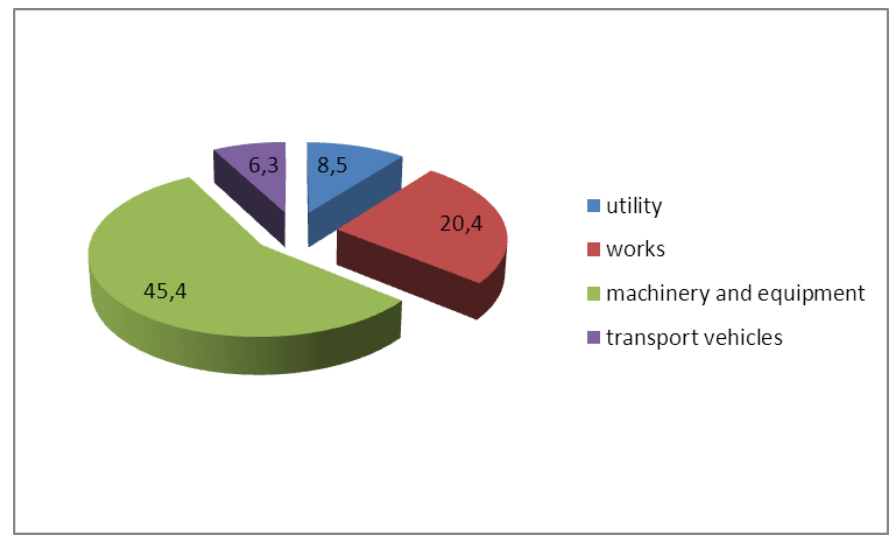

Fig. 4. The structure of the elements of wholesale and retail trade fixed assets in 2016

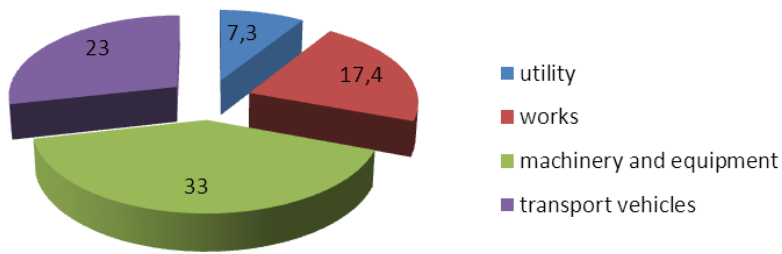

Fig. 5. The structure of the elements of permanent assets of mining operations in 2016

With reference to the data shown in Figures 4 and 5, a conclusion can be made that the maximum specific weight in the structure of fully depreciated fixed assets is accounted for by machinery and equipment: $45.4 \%$ in wholesale and retail trade and $33 \%$ in mining operations, as well as works: $20.4 \%$ and $17.4 \%$ branch-wise accordingly [18]. The given situation can be conditioned by peculiarity and capital intensity of these branches, but high values of the given index numbers can be indicative of the need of timely fixed assets renewal.

Next, there is a need to analyze one of the main sources of funds for reproduction of capital of an enterprise and the instrument of depreciation remuneration, such as depreciation charges:

TABLE V. FIXED ASSETS AMORTISATION CALCULATED FOR A REFERENCE YEAR IN PROFIT ORGANIZATIONS (WITHOUT SMALL BUSINESSES) BY LINES OF BUSINESS

\begin{tabular}{|c|c|c|c|}
\hline \multicolumn{4}{|c|}{ million rubles } \\
\hline All fixed assets & 4179492 & 4751927 & 5297692 \\
\hline \multicolumn{4}{|c|}{ by line of business including: } \\
\hline \begin{tabular}{|lll}
$\begin{array}{l}\text { agriculture, hunting } \\
\text { forestry }\end{array}$ & and \\
\end{tabular} & 133513 & 150175 & 164597 \\
\hline fishery and fish breeding & 4735 & 5337 & 5483 \\
\hline mining operations & 871075 & 969720 & 1181380 \\
\hline manufacturing activities & 726923 & 932008 & 1039223 \\
\hline $\begin{array}{l}\text { production and distribution of } \\
\text { electricity, gas and water }\end{array}$ & 446763 & 509874 & 528935 \\
\hline building & 86794 & 98824 & 99585 \\
\hline $\begin{array}{l}\text { wholesale and retail trade; } \\
\text { repair of vehicles, motorcy- } \\
\text { cles, household goods, } \\
\text { personal hygiene items }\end{array}$ & 593109 & 594701 & 705194 \\
\hline hotels and restaurants & 13081 & 15654 & 24330 \\
\hline transport and communication & 762519 & 816679 & 857342 \\
\hline financing activity & 241734 & 255597 & 273108 \\
\hline $\begin{array}{l}\text { real estate activities, lease and } \\
\text { provision of services }\end{array}$ & 251526 & 347050 & 364622 \\
\hline $\begin{array}{l}\text { public administration and } \\
\text { defence; compulsory social } \\
\text { maintenance }\end{array}$ & 502 & 515 & 1095 \\
\hline education & 183 & 139 & 178 \\
\hline $\begin{array}{l}\text { public health and rendering } \\
\text { of social services }\end{array}$ & 9660 & 9673 & 13808 \\
\hline $\begin{array}{l}\text { provision of other municipal, } \\
\text { social and personal services }\end{array}$ & 37375 & 45981 & 38812 \\
\hline \multicolumn{4}{|c|}{\begin{tabular}{|c} 
as percentage of fixed assets availability at the beginning of the reporting year \\
by full book value
\end{tabular}} \\
\hline \begin{tabular}{|c|} 
All fixed assets \\
\end{tabular} & 6.6 & 6.7 & 6.5 \\
\hline \multicolumn{4}{|c|}{ by line of business including: } \\
\hline $\begin{array}{l}\text { agriculture, hunting and } \\
\text { forestry }\end{array}$ & 8.5 & 8.4 & 8.5 \\
\hline fishery and fish breeding & 7.3 & 7.4 & 8.0 \\
\hline mining operations & 9.1 & 8.6 & 9.1 \\
\hline manufacturing activities & 8.1 & 8.4 & 8.2 \\
\hline \begin{tabular}{|l|} 
production and distribution of \\
electricity, gas and water
\end{tabular} & 5.8 & 5.8 & 5.6 \\
\hline building & 10.5 & 10.2 & 9.4 \\
\hline $\begin{array}{l}\text { wholesale and retail trade; } \\
\text { repair of vehicles, motorcy- } \\
\text { cles, household goods, } \\
\text { personal hygiene items }\end{array}$ & 4.1 & 4.2 & 4.1 \\
\hline hotels and restaurants & 6.4 & 6.7 & 7.9 \\
\hline transport and communication & 5.6 & 5.5 & 5.1 \\
\hline financing activity & 12.6 & 12.1 & 11.5 \\
\hline $\begin{array}{l}\text { real estate activities, lease and } \\
\text { provision of services }\end{array}$ & 7.4 & 6.7 & 5.9 \\
\hline $\begin{array}{l}\text { public administration and } \\
\text { defence; compulsory social } \\
\text { maintenance }\end{array}$ & 6.8 & 4.8 & 6.3 \\
\hline education & 5.0 & 4.2 & 3.4 \\
\hline $\begin{array}{l}\text { public health and rendering } \\
\text { of social services }\end{array}$ & 7.5 & 6.2 & 7.8 \\
\hline $\begin{array}{l}\text { provision of other munici- } \\
\text { pal, social and personal } \\
\text { services }\end{array}$ & 10.4 & 11.7 & 8.7 \\
\hline
\end{tabular}


Basing on the data given in Table 5 (part 1 - in million rubles), it is reasonable to construct a graph reflecting the structure of calculated amortization by lines of business:

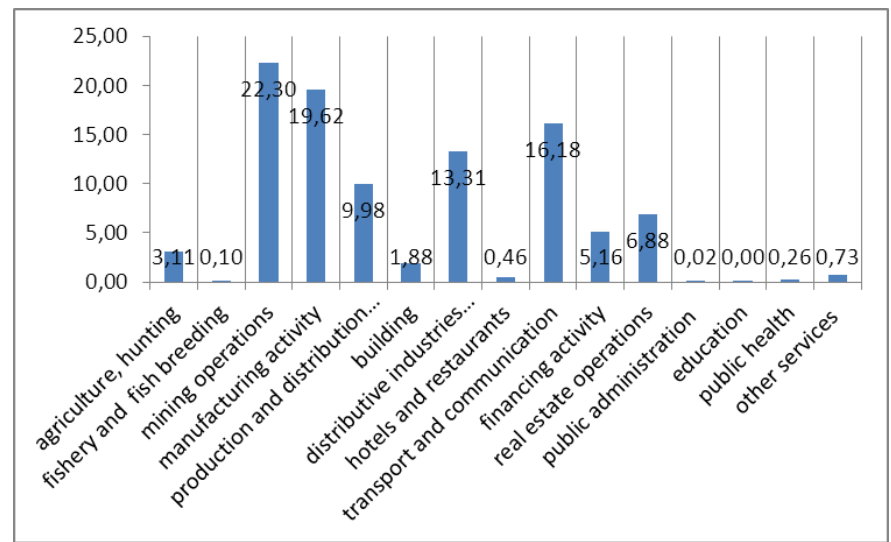

Fig.8. The structure of calculated amortization in 2016

On the basis of Figure 8, one can conclude that the most specific weight in the structure of calculated amortization is accounted for by the following branches:

- mining operations: $22.3 \%$;

- manufacturing activities: $19.62 \%$;

- transport and communication: $16.18 \%$;

- wholesale and retail trade: $13.31 \%$;

- production and distribution of electricity, gas and water: 9.98\%;

Further relying on the data of Table 5 (part 2 - as percentage of fixed assets availability at the beginning of the reporting year by full book value), one can visually represent the dynamics of values changing by lines of business having the maximum specific weight:

Thus, following Figure 9 and Table 5, it can be seen that the amount of amortization charges increases, which creates an opportunity of reprocessing and renewal of depreciated articles of fixed assets. The need of the priority branch way of articles of fixed assets renewal, set in motion by specifications and capital requirements of production, is confirmed.

However taking into account qualitative value of the given index number level ( $\%$ to fixed assets availability), it is apparent that the renewal process is at a very low level that does not ensure high efficiency of the held activities.

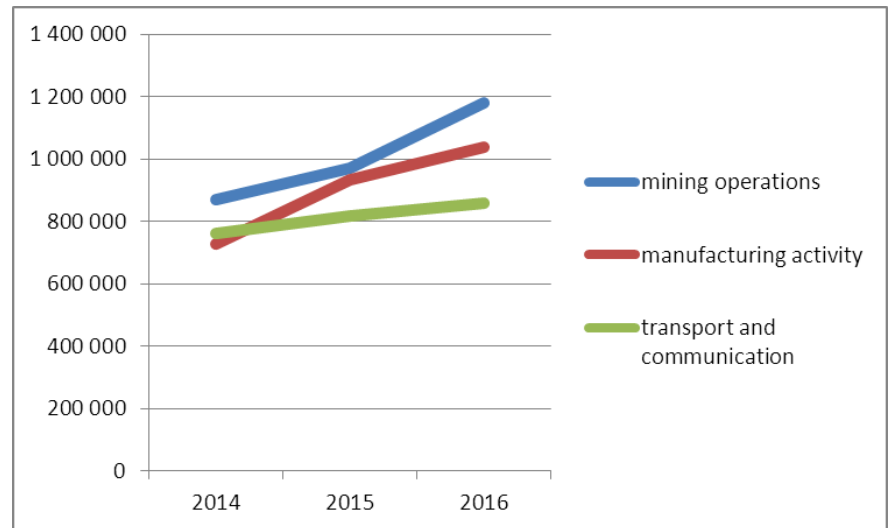

Fig. 9. The dynamics of calculated amortization changing by lines of business

\section{CONCLUSION}

In accordance with the carried out analyses two main groups of problem aspects preventing from the renewal of articles of fixed assets can be made:

1) Internal ones: the lack of vast amounts of finances and the reluctance of leaders to divert vast amounts of finances, deficiency of technical innovation, production area and etc.;

2) Exogenous ones: high market prices, tax liability, stiff competition and etc.

Provided that, the necessity of the renewal of fixed assets, which is specified by matter of course - wear and tear, cannot be underestimated [17]. These factors imply their consenescence and loss in value, decline in output (production cut and diseconomy for repair costs and service work) and marketed competitive power of output (services). The high level of depreciation also creates a threat for operation safety and production operation accident risk [8].

As the main factors facilitating efficiency of upgrading of fixed assets renewal, the following can be singled out:

TABLE VI - EFFICIENCY FACTORS OF ARTICLES OF FIXED ASSETS RENEWAL OF A BUSINESS ENTERPRISE

\begin{tabular}{|l|l|}
\hline \multicolumn{2}{|c|}{ Groups of factors } \\
\hline Efficiency upgrading & Hampering \\
\hline Depreciation policy & $\begin{array}{l}\text { Safety: } \\
\text { - accident rate; } \\
\text { - repair and etc. }\end{array}$ \\
\hline High yield of investment & Ecological factors \\
\hline Low charges & Export surety \\
\hline Optimal structure of fixed assets & Branch specification \\
\hline Capital renewal & Tax liability \\
\hline
\end{tabular}

\section{RECOMMENDATIONS}

For the renewal optimization procedure of articles of fixed assets, it is necessary to update depreciation policy (popularization of accelerated depreciation and enhancing of depreciation rates) and attract investments into fixed capital assets (for this, one must create congenial investment climate - export 
processing zones, a high level of capital investment safety, innovative activity rising and etc.).

\section{References}

[1] T.N. Myznikova, E.V. Bunova and E.N. Yaroslavova, «Modeling the formation of an industrial enterprise operating income», SHS Web Conf., Volume 35, 3rd International Conference on Industrial Engineering (ICIE-2017), pp. 1 - 5, 26 June 2017.

[2] M.K. Akhtyamov and E.A. Gonchar, «Financial capital appraisal in the system of industrial enterprise development management», SHS Web Conf., Volume 35, 3rd International Conference on Industrial Engineering (ICIE-2017), pp. 2 - 6, 26 June 2017.

[3] A.D. Radygin, L.M. Freinkman, N. Glavatskaya, «Russian Economy in 2013. Trends and outlooks», IET - Foundation Gaidar Institute for Economic Policy, Volume 35, pp. 387-393, 2015.

[4] S.V. Savin, «Managing capital intensive rental businesses», University of Pennsylvania: 0796 - Operations research, 0454 - Business administration, management, Volume 1, pp. 156-167, 2016.

[5] O.N. Ivanyta, «Role of capital market businesses commercial establishment», Economic and management: theory and practice, Group of scientific articles, Publisher SWG imex GmbH, pp. 77-83, 2015.

[6] C.A. Romano, G.A. Tanewski, K.X. Smyrnios, «Capital structure decision making», Elsevier Science Publishing Company, Inc. - Journal of business venturing, Volume 16, number 3, pp. 235-246, 2014.

[7] M. Campello, «Capital structure and product markets interactions: evidence from business cycles», Elsevier Science Publishing Company, Inc. - Journal of Financial Economics (ISSN: 0304-405X), Volume 68, number 3, pp. 312-325, 2015.

[8] D. Delano, «Business capital spending still propels economic growth», Reed Business Information - Modern materials handling, Volume 50, number 14, pp. 3-7, 2016.
[9] Rodney McAdam, Eamonn McCarron, «Strategic business improvement approaches to capital expenditure processes in manufacturing», Emerald Group Publishing Limited, Integrated manufacturing syatems, Volume 13, number 1, pp. 7-17, 2016.

[10] C.E. Alper, «Advantage capital open for business», Proquest ABI/INFORM - European venture capital journal, Volume 78, number 2, pp. 4-9, 2015.

[11] N.R. Huyghebaert, «The capital structure of business start-ups», Katholieke Universiteit Leuven (Belgium): 0454, Business administration, management, 0505 - Economics, commerce-business, 0508 - Economics, finance, Volume 69, pp. 2-11, 2017.

[12] Online resource - access mode: http://www.gks.ru/wps/wcm/connect/rosstat_main/rosstat/ru/statistics/en terprise/fund/\#

[13] [Electronic version] - Online resource «All about financial analysis», access mode: http://1 fin.ru/?id=311\&t=28

[14] [Electronic version] - Online resource "Encyclopedia of the Economist", access mode: http://www.grandars.ru/student/statistika/pokazatelidvizheniya-osnovnyh-fondov.html, date of circulation: August 2017;

[15] [Electronic version] - Electronic portal on accounting and tax accounting, access mode: http://online-buhuchet.ru/koefficient-iznosaosnovnyx-sredstv

[16] A.S. Nechaev, O.V. Antipina, "Technique of tax rates and customs duties updating as the tool of enterprises innovative activity stimulation,” Modern Applied Science, № 9 (2), pp. 88-96, 2015.

[17] A. Nechaev, O. Antipina, "Tax stimulation of innovation activities enterprises,” Mediterranean Journal of Social Sciences, № 6 (1S2) pp. 42-47, 2015.

[18] A.S. Nechaev, O.V. Antipina, A.V. Prokopyeva, "The risks of innovation activities in enterprises," Life Science Journal, № 11 (11), 102, pp. 574-575, 2014. 